\title{
TITLE:
}

\section{Contributors to the Original Report}

$\operatorname{AUTHOR}(\mathrm{S})$ :

\section{CITATION:}

Contributors to the Original Report. Pan Africa News 1994, 1(2): 1-1

ISSUE DATE:

1994-06

URL:

http://hdl.handle.net/2433/143547

\section{RIGHT:}

Copyright (C) Pan Africa News. 


\section{Pan africanews}

The Newsletter of the Japan Committee for the Conservation and Care of Chimpanzees and the Mahale Wildlife Conservation Society

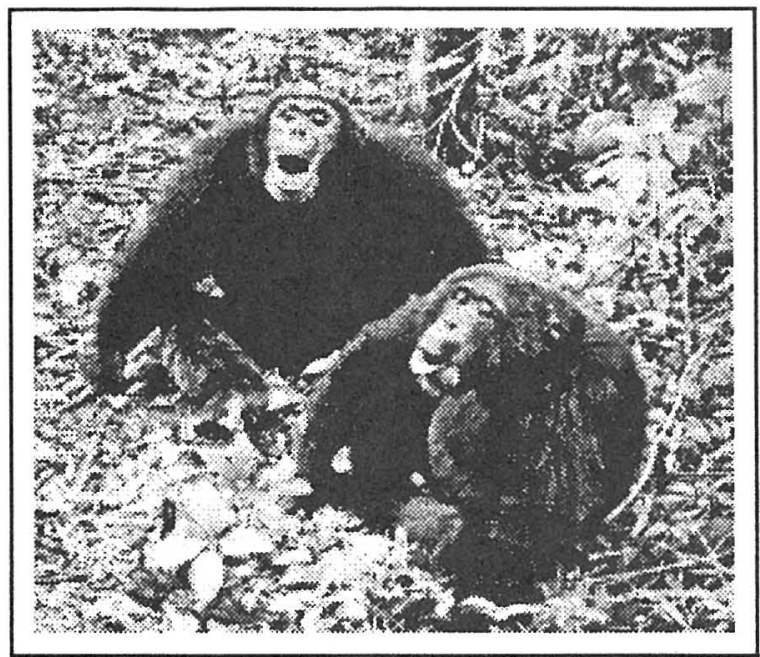

\section{FROM THE EDITOR:}

This special edition of Pan Africa News contains sections of a previously unpublished report compiled by $\mathrm{T}$. Nishida on the distribution and status of chimpanzee populations in Africa. The report describes the way things were in 1987-1989. Obviously, given the pace of change in the world, the information is in need of revision; we would like therefore to use this material as a foundation for creating a "new and improved" version and see it through to publication, perhaps in the form of an action plan for chimpanzee conservation.

The original report was compiled through the use of questionnaires, and a great number of people contributed to the effort (see Contributors below). The questionnaire is duplicated here, and we would be most appreciative should readers with more current information about their geographical areas of research wish to take the time to complete it and return it to us. For more information about the report or a list of references please contact the Editor. LAT

\section{CONTRIBUTORS TO THE ORIGINAL REPORT:}

The original questionnaires were prepared by M. Hiraiwa-Hasegawa and T. Nishida. White maps and a provisional list of field primatologists were prepared by Y. Takahata. Key contributors of information were: J. Reifschneider and P.C. Trenchard (Burundi); A.H. Harcourt, A.H. Pierce,A. Vedder, A.W. Weber and J. Yamagiwa (Rwanda); T.M. Butynski, A.H. Harcourt, P.C. Howard, J. Moore, W.T. Jones, P. Waser and R.W. Wrangham (Uganda); J. Goodall, E. Massawe, J. Moore and T. Nishida (Tanzania); C. Aveling, M. Ichikawa, T. Tanno, H. Terashima and J. Yamagiwa (Zaire); M.J.S. Harrison, J. Hoshino, M. Mitani, A. Mori, H. Ohsawa and T. Rowell (Cameroon); S. Kuroda, M. Mitani, J. Moore and T. Tanno (Congo); J. Sabater Pi (Rio Muni); C.E.G. Tutin and E.A. Williamson (Gabon); A.H. Harcourt and D. Thomas (Nigeria); S.H. Curtin (Ghana); C. Boesch (Ivory Coast); A.G. Davies, R.S.O. Harding and J. Oates (Sierra Leone); W.C. McGrew (Senegal); J. Moore (Mali). 